\begin{tabular}{|c|c|c|c|c|}
\hline Share: Social Work Jurnal & VOLUME: 11 & NOMOR: 2 & HALAMAN: $81-88$ & $\begin{array}{c}\text { ISSN: 2339-0042 (p) } \\
\text { ISSN: 2528-1577 (e) } \\
\text { DOI: } 10.24198 / \text { share.v11i2.37040 }\end{array}$ \\
\hline
\end{tabular}

\title{
UPAYA PENI NGKATAN KAPASITAS KELUARGA DALAM PENGASUHAN ANAK \\ (Studi Kasus Pada Proses Perlindungan Anak Terlantar oleh Rumah Perlindungan Sosial Asuhan Anak (RPSAA) Ciumbuleuit Kota Bandung)
}

\section{EFFORTS TO INCREASE THE CAPACI TY OF FAMI LI ES IN CHI LD CARE (Case Study on the Process of Neglected Children Protection by the Children's Social Protection House in Ciumbuleuit Bandung City)}

\author{
Gina Indah Permata Nastia ${ }^{1}$, Sri Sulastri ${ }^{2}$, dan Eva Nuriyah ${ }^{3}$ \\ 1,2,3Program Studi Pascasarjana IImu Kesejahteraan Sosial Universitas Padjadjaran \\ gina19007@mail.unpad.ac.id ${ }^{1}$, sri.sulastri@unpad.ac.id², enuriyah@yahoo.co.id ${ }^{3}$
}

Submitted : 9 Desember 2021; Accepted : 24 Desember 2021; Published : 1 Februari 2022

\begin{abstract}
ABSTRAK
Penelantaran anak merupakan salah satu kasus perlakuan salah terhadap anak yang banyak terjadi di Indonesia, disamping kekerasan dan eksploitasi. Provinsi Jawa Barat merupakan salah satu provinsi di Indonesia dengan persentase anak terlantar yang tinggi, yakni sebesar 1,26\% atau sebanyak 22.122 anak terlantar. Angka tersebut merupakan angka tertinggi di Pulau Jawa. Masalah penelantaran anak ini perlu diatasi, karena memiliki sejumlah konsekuensi terhadap perkembangan dan pertumbuhan anak. Guna menangani masalah tersebut, diperlukan upaya perlindungan anak terlantar melalui lembaga pengasuhan alternatif, yakni panti asuhan. Namun, panti asuhan di Indonesia memiliki permasalahan rendahnya kualitas sistem pelayanan, di mana panti asuhan di Indonesia lebih berfungsi sebagai lembaga yang menyediakan pelayanan berupa akses terhadap pendidikan daripada sebagai lembaga yang menyediakan pengasuhan alternatif terakhir bagi anak yang mendukung sistem pengasuhan berbasis keluarga. Penelitian ini bertujuan untuk mendeskripsikan pelayanan bagi keluarga dalam proses perlindungan anak terlantar oleh Rumah Perlindungan Sosial Asuhan Anak (RPSAA) Ciumbuleuit Kota Bandung, sebagai upaya peningkatan kapasitas pengasuhan keluarga. Adapun penelitian ini menggunakan metode penelitian kualitatif dan jenis penelitian deskriptif kualitatif, dengan jumlah informan sebanyak 11 orang, yakni terdiri dari 5 orang pekerja sosial yang bertugas di RPSAA Ciumbuleuit Kota Bandung, dan 1 keluarga yang menerima pelayanan dari RPSAA Ciumbuleuit Kota Bandung. Hasil penelitian menunjukkan bahwa pelayanan bagi keluarga oleh RPSAA Ciumbuleuit Kota Bandung belum dilaksanakan secara maksimal, mulai dari tahap pendekatan awal hingga tindak lanjut. Oleh karena itu, lembaga perlu mengatur kembali pelaksanaan tahap asesmen hingga tindak lanjut, serta mengembangkan pelayanan bagi keluarga yang sesuai dengan permasalahan dan kebutuhan keluarga.
\end{abstract}

Kata Kunci: penelantaran anak, perlindungan anak, panti asuhan, pelayanan, keluarga 


\begin{abstract}
Child neglect is one of the most common cases of child abuse in Indonesia, in addition to violence and exploitation. West Java is one of the provinces in Indonesia with a highest percentage of neglected children in Java, namely $1.26 \%$ or 22, 122 neglected children. This problem needs to be addressed, because it has a number of consequences on children's development and growth. In order to deal with this problem, it is necessary to protect neglected children through alternative care institutions, namely orphanages. However, orphanages in Indonesia have low quality service system. They function more as institutions that provide services in the form of access to education rather than as institutions that provide the last alternative care for children that supports a family-based care system. This study aims to describe families' services in the neglected children protection process by the Children's Social Protection Home (CSPH) Ciumbuleuit Bandung City, as an effort to increase the capacity of family care. This research uses qualitative research methods and qualitative descriptive research types, with the number of informants as many as 11 people, consisting of 5 social workers on duty at CSPH Ciumbuleuit Bandung City, and 1 family receiving services from CSPH Ciumbuleuit Bandung City. The results showed that services for families had not been implemented optimally by CSPH Ciumbuleuit Bandung City, starting from the initial approach stage to follow-up. Therefore, the institution needs to reorganize the implementation of the assessment to follow-up stage, as well as develop services for families that are appropriate with the problems and needs of the family.
\end{abstract}

\title{
Keywords: child neglect, child protection, orphanage, service, family
}

\section{PENDAHULUAN}

Penelantaran anak merupakan salah satu kasus perlakuan salah terhadap anak yang banyak terjadi di Indonesia, disamping kasus kekerasan terhadap anak dan eksplotasi, terutama saat pandemi COVID-19. Kasus penelantaran anak berdasarkan data Kementerian Sosial pada bulan Juni 2020 mencapai 766 kasus dan bertambah menjadi 1.116 kasus pada bulan Juli 2020, serta 1.247 kasus pada bulan Agustus 2020. Sedangkan hingga 15 Desember 2020, tercatat sebanyak 67.368 anak terlantar di Indonesia. Kasus penelantaran tersebut secara keseluruhan dilakukan oleh keluarga sendiri (Amrullah, 2020).

Tindakan penelantaran dapat menyebabkan dampak negatif terhadap anak, meliputi kesulitan sosial dan keterikatan yang terganggu antara orang tua dan anak, gangguan interaksi dengan teman sebaya, defisit kognitif dan akademik, masalah emosional dan perilaku (seperti sikap apatis dan menarik diri, rasa berharga yang rendah, agresi fisik dan verbal, gangguan psikis, dan sebagainya), konsekuensi fisik (seperti kematian, kegagalan untuk berkembang), serta konsekuensi jangka panjang (seperti defisit kognitif, perilaku kriminal, gangguan psikis, masalah alkohol, kemiskinan, kebutuhan akan pendidikan khusus, putus sekolah, pola asuh yang tidak memadai) (P. Cohen, Brown, $\&$ Smailes, 2001; Conron, Beardslee, Koenen, Buka, \& Gortmaker, 2009; Erickson \& Egeland, 2010; Gil et al., 2009; Hildyard \& Wolfe, 2002; Sroufe, Egeland, Carlson, \& Collins, 2005; Widom, Czaja, \& Dutton, 2008 dalam Barnett et al., 2011). Lembaga pengasuhan alternatif, seperti panti asuhan, dibutuhkan untuk perlindungan sehingga kesejahteraan anak terlantar dapat terwujud.

Panti asuhan adalah lembaga pengasuhan alternatif yang menyediakan pengaturan tempat tinggal bagi lebih dari sepuluh anak tanpa orang tua atau orang tua pengganti, di mana pengasuhan diberikan oleh pengasuh dewasa yang dibayar dan jumlahnya jauh lebih sedikit (Browne, 2009). Pengasuhan alternatif oleh lembaga ini bersifat sementara, dan tujuan utamanya adalah mengupayakan sistem Family Based Care melalui penyatuan kembali atau reunifikasi anak dengan keluarganya sesegera mungkin untuk anak-anak yang sudah ditempatkan di lembaga (Fernandez, 2013; Sanchiricho \& J ablonka, 2000; Permensos RI No. 30 Tahun 2011; Garfunkel, Kaczorowski, \& Christy, 2007). Sistem Family Based Care ini merupakan sistem pengasuhan terbaik bagi anak. $\mathrm{Hal}$ ini dikarenakan keluarga memiliki tanggungjawab dalam pengasuhan anak dan memiliki peran penting bagi kesejahteraan anak (Bigner \& Gerhardt, 2014; Deb, 2018).

Namun, penelitian lain mengungkapkan bahwa ada beberapa faktor penyebab penelantaran anak, yakni antara lain faktor keluarga, faktor yang 


\begin{tabular}{|c|c|c|c|c|}
\hline Share: Social Work Jurnal & VOLUME: 11 & NOMOR: 2 & HALAMAN: $81-88$ & $\begin{array}{c}\text { ISSN: 2339-0042 (p) } \\
\text { ISSN: } 2528-1577(e) \\
\text { DOI: } 10.24198 / \text { share.v11i2.37040 }\end{array}$ \\
\hline
\end{tabular}

berasal dari luar keluarga, dan faktor budaya (McCoy \& Keen, 2014). Faktor keluarga sebagai pelaku tindakan penelantaran anak di antaranya meliputi jenis kelamin orang tua/keluarga pengganti, penyalahgunaan zat pada orang tua/keluarga pengganti, gangguan kesehatan mental dan masalah kepribadian pada orang tua/keluarga pengganti, serta struktur dan disfungsi keluarga. Faktor di luar keluarga meliputi kurangnya dukungan sosial dari keluarga besar, teman, dan pelayanan sosial, atau dengan kata lain, kondisi keluarga yang terisolasi secara sosial. Selain kurangnya dukungan dari luar, faktor kemiskinan turut menentukan. Selanjutnya, faktor budaya meliputi budaya yang menerima tindakan perlakuan salah terhadap anak di dalam keluarga (McCoy \& Keen, 2014). Faktor keluarga merupakan faktor yang paling kuat dari faktor-faktor lainnya pada penelantaran anak (Stith et al., 2009; Mulder et al., 2018).

Layanan bagi keluarga oleh lembaga pengasuhan alternatif perlu disediakan, contohnya layanan yang dapat meningkatkan kapasitas pengasuhan keluarga. Upaya tersebut dapat dilakukan dengan menyediakan berbagai macam layanan yang dibutuhkan oleh anak dan keluarga, seperti konseling individu, pendidikan pengasuhan, terapi keluarga, dan sebagainya; dan/atau menyediakan professional dari berbagai bidang keilmuan, seperti penegak hukum, pengadilan, sekolah, rumah sakit, dan lain sebagainya (Gaudin, 1993). Upaya peningkatan kapasitas pengasuhan keluarga ini perlu dilakukan, karena keluarga merupakan lingkungan yang memberikan dampak paling besar terhadap perkembangan anak (Mulder et al., 2018) dan memiliki tanggung jawab dalam pengasuhan anak (Bigner \& Gerhardt, 2014).

Provinsi Jawa Barat merupakan salah satu provinsi di Indonesia yang memiliki persentase anak terlantar yang tinggi, yakni sebesar $1,26 \%$ atau sebanyak 22.122 anak terlantar. Angka tersebut merupakan angka tertinggi di antara provinsiprovinsi lainnya di Pulau Jawa, dan lebih tinggi dibandingkan dengan beberapa provinsi lainnya di luar Pulau J awa (Profil Anak I ndonesia KemenPPPA, 2019). Berdasarkan data PMKS Dinas Sosial Provinsi J awa Barat Tahun 2019, jumlah anak terlantar (usia 6 hingga 18 tahun) di Provinsi Jawa Barat sebanyak 101.233 anak. Angka tersebut merupakan angka tertinggi dibandingkan dengan jenis Penyandang Masalah Kesejahteraan Sosial (PMKS) lainnya, seperti anak korban tindak kekerasan (15.217 anak), anak gelandangan (15.217 anak), anak balita terlantar (11.720 anak), anak jalanan (11.600 anak), anak yang memerlukan perlindungan khusus ( 7.518 anak), dan anak berhadapan dengan hukum (3.595 anak). Penanganan terhadap anak terlantar di Provinsi Jawa Barat ini perlu dilakukan, karena kondisi tersebut dapat berpengaruh terhadap pertumbuhan dan perkembangan anak. Dalam hal ini, panti asuhan di Provinsi Jawa Barat perlu mengimplementasikan proses perlindungan anak terlantar yang mendukung sistem pengasuhan berbasis keluarga melalui upaya peningkatan kapasitas pengasuhan keluarga, agar anak dapat memperoleh pengasuhan yang optimal dari keluarganya.

Penelitian ini bertujuan untuk menggambarkan pelayanan bagi keluarga oleh Rumah Perlindungan Sosial Asuhan Anak (RPSAA) Ciumbuleuit Kota Bandung dalam perlindungan anak terlantar, sebagai upaya untuk meningkatkan kapasitas keluarga dalam pengasuhan anak. RPSAA Ciumbuleuit Kota Bandung ini merupakan salah satu lembaga perlindungan anak milik Dinas Sosial Provinsi Jawa Barat yang keberadaannya merupakan respon pemerintah dalam menangani masalah anak terlantar di Provinsi Jawa Barat. Namun, terdapat permasalahan dalam proses perlindungan anak terlantar di lembaga tersebut, di mana sebagian besar anak di lembaga tersebut direunifikasi atau dikembalikan kepada keluarga setelah mereka menyelesaikan pendidikan SMA. Padahal, sistem pengasuhan berbasis keluarga perlu diupayakan sedini mungkin, karena pengasuhan berbasis keluarga merupakan sistem pengasuhan terbaik bagi pertumbuhan dan perkembangan anak dibandingkan dengan sistem pengasuhan berbasis lembaga (Browne, 2009; J ohnson, Browne, \& Hamilton-Giachritsis, 2006).

\section{METODE}

Penelitian ini dilakukan pada bulan November 2020 hingga November 2021 di Rumah Perlindungan Sosial Asuhan Anak (RPSAA) Ciumbuleuit Kota Bandung. Metode penelitian yang digunakan adalah metode penelitian kualitatif dengan jenis penelitian deskriptif kualitatif. Metode ini digunakan untuk menggambarkan secara jelas dan terperinci mengenai pelayanan bagi keluarga yang dilakukan oleh RPSAA Ciumbuleuit Kota Bandung dalam perlindungan anak terlantar. Pemilihan informan dilakukan dengan menggunakan teknik purposive, dengan berdasarkan pada beberapa kriteria, yakni informan terlibat secara aktif dalam proses perlindungan anak terlantar di RPSAA Ciumbuleuit Kota Bandung, informan dianggap memiliki pengetahuan yang memadai mengenai informasi yang dibutuhkan oleh peneliti, dan informan bersedia untuk diwawancarai. Subjek yang dijadikan sebagai informan dalam penelitian ini meliputi 5 orang 


\begin{tabular}{|c|c|c|c|c|}
\hline Share: Social Work Jurnal & VOLUME: 11 & NOMOR: 2 & HALAMAN: $81-88$ & $\begin{array}{c}\text { ISSN: 2339-0042 (p) } \\
\text { ISSN: 2528-1577 (e) } \\
\text { DOI: } 10.24198 / \text { share.v11i2.37040 }\end{array}$ \\
\hline
\end{tabular}

pekerja sosial yang bertugas di RPSAA Ciumbuleuit Kota Bandung dan 1 keluarga dari anak asuh yang memperoleh manfaat dari lembaga tersebut.

\section{HASI L DAN PEMBAHASAN}

Santoso (2005) mendefinisikan panti asuhan sebagai suatu lembaga yang berfungsi untuk membentuk perkembangan anak-anak yang tidak memiliki keluarga ataupun yang tidak tinggal bersama keluarga. Selanjutnya, Permensos RI No. 30 Tahun 2011 tentang Standar Pelayanan LKSA menyebutkan bahwa LKSA adalah lembaga yang menangani anak yang membutuhkan pengasuhan alternatif. Panti asuhan ini merupakan lembaga yang menyediakan dan menyelenggarakan perlindungan anak dengan mengambil alih fungsi keluarga pada saat lingkungan keluarga membahayakan atau menghambat pertumbuhan dan perkembangan anak.

Pengasuhan alternatif berbasis lembaga atau panti asuhan bersifat sementara, dan tujuannya adalah mengupayakan penyatuan kembali atau reunifikasi anak dengan keluarganya sesegera mungkin untuk anak-anak yang sudah ditempatkan di panti asuhan (Garfunkel, Kaczorowski, \& Christy, 2007; Fernandez, 2013; Sanchiricho \& Jablonka, 2000; Permensos RI No. 30 Tahun 2011). Guna mengupayakan pengasuhan berbasis keluarga atau Family Based Care, panti asuhan dalam hal ini selain memberikan pelayanan kepada anak yang terkena dampak dari penelantaran, juga perlu memberikan penguatan atau intervensi kepada keluarga dan lingkungan tempat tinggal anak, dan tetap memberikan dukungan yang dibutuhkan untuk membangun kapasitas keluarga dalam memberikan pengasuhan (Gaudin, 1993; Fernandez, 2013; Preston-Shoot, 2007; Permensos RI No. 30 Tahun 2011).

Penelitian ini dilakukan terhadap perlindungan anak terlantar di Rumah Perlindungan Sosial Asuhan Anak (RPSAA) Ciumbuleuit Kota Bandung. Teknik yang dilakukan pada penelitian ini meliputi teknik wawancara, observasi, dan dokumentasi. Wawancara dilakukan terhadap lima orang pekerja sosial; lima orang anak asuh, yang terdiri dari anak korban penelantaran fisik, penelantaran emosional, penelantaran pendidikan, penelantaran kesehatan, dan kombinasinya; serta keluarga dari anak asuh, yang terdiri dari pelaku tindakan penelantaran fisik, penelantaran emosional, penelantaran pendidikan, penelantaran kesehatan, dan kombinasinya. Wawancara dilakukan pada bulan Oktober hingga November 2021, sedangkan observasi dilakukan pada bulan November 2021 di RPSAA Ciumbuleuit Kota Bandung. Dalam penelitian ini, peneliti memperoleh temuan mengenai pelayanan bagi keluarga yang dilakukan oleh Rumah Perlindungan Sosial Asuhan Anak (RPSAA) Ciumbuleuit Kota Bandung, sebagai berikut.

\section{Pendekatan Awal}

Sebelum melakukan pendekatan awal terhadap keluarga dari anak terlantar, pekerja sosial yang bertugas di RPSAA Ciumbuleuit Kota Bandung melakukan kegiatan sosialisasi program kepada Dinas Sosial Kabupaten/Kota, TKSK, TAGANA, pendamping $\mathrm{PKH}$, dan masyarakat daerah setempat, serta memperoleh informasi mengenai keberadaan keluarga dari anak terlantar. Setelah informasi mengenai keberadaan keluarga diperoleh, pekerja sosial kemudian melakukan penjangkauan keluarga dengan melakukan kunjungan ke rumah keluarga.

Dalam pelaksanaan kunjungan ke rumah keluarga, pekerja sosial memulai pendekatan awal terhadap keluarga dengan mensosialisasikan program terlebih dahulu kepada keluarga. Setelah itu, pekerja sosial melakukan kegiatan-kegiatan untuk memastikan bahwa pemenuhan kebutuhan dasar anak tidak dapat dilakukan oleh keluarga, yakni diantaranya dengan pengisian formulir oleh keluarga, wawancara dan observasi. Jika keluarga sudah terbukti tidak dapat memenuhi kebutuhan dasar anak, maka pekerja sosial akan berkomunikasi dengan keluarga untuk membangun kepercayaan keluarga agar keluarga bersedia untuk menerima layanan dari lembaga. Setelah pekerja sosial memperoleh kepercayaan dan persetujuan dari keluarga, pekerja sosial selanjutnya membuat kontrak bersama keluarga dan anak yang menyatakan bahwa seluruh pihak setuju untuk menempatkan anak di RSPAA Ciumbuleuit tanpa paksaan. Setelah kontrak disetujui, keluarga kemudian diminta untuk melampirkan Surat Keterangan Tidak Mampu (SKTM), Kartu Keluarga, Kartu Tanda Penduduk (KTP), Akte Kelahiran anak, serta surat bukti yang menunjukkan bahwa keluarga terdaftar dalam Data Terpadu Kesejahteraan Sosial (DTKS), sebagai pertimbangan saat case conference penerimaan anak.

\section{Asesmen}

RPSAA Ciumbuleuit Kota Bandung memiliki pedoman asesmen yang dapat digunakan oleh para pekerja sosial sebagai panduan. Pedoman tersebut berisi tentang aspek-aspek apa saja yang diidentifikasi dalam proses asesmen keluarga, diantaranya identitas keluarga, termasuk pendidikan, pekerjaan, penghasilan, jumlah tanggungan keluarga, keluarga besar, kepemilikan 


\begin{tabular}{|c|c|c|c|c|}
\hline Share: Social Work Jurnal & VOLUME: 11 & NOMOR: 2 & HALAMAN: $81-88$ & $\begin{array}{c}\text { ISSN: 2339-0042 (p) } \\
\text { ISSN: 2528-1577 (e) } \\
\text { DOI: } 10.24198 / \text { share.v11i2.37040 }\end{array}$ \\
\hline
\end{tabular}

rumah, serta bangunan dan ukuran rumah; situasi dan kondisi keluarga yang ditempati anak saat ini, termasuk dengan siapa anak tinggal, relasi anak dengan yang ditinggali, jumlah anggota keluarga, kondisi tempat tinggal, lingkungan kesehatan tempat tinggal, dan kondisi ekonomi keluarga; serta situasi pengasuhan keluarga, termasuk relasi orang tua dan anak, relasi antar anak, pola pengasuhan keluarga, dan pandangan orang tua tentang anak. Namun, pada pelaksanaannya pedoman tersebut tidak digunakan oleh semua pekerja sosial dalam proses asesmen.

Dalam proses asesmen, pekerja sosial juga mengidentifikasi tindakan penelantaran oleh orang tua atau keluarga terhadap anak untuk memastikan bahwa layanan lembaga pengasuhan alternatif dibutuhkan oleh anak. Informasi mengenai kondisi orang tua atau keluarga secara individu juga diidentifikasi oleh beberapa pekerja sosial, diantaranya mengenai kesehatan fisik dan mental orang tua, kesiapan orang tua dalam memberikan pengasuhan, dan hubungan yang terjalin di antara setiap anggota keluarga. Informasi tersebut didapatkan melalui wawancara langsung kepada orang tua atau keluarga, dan juga kepada pihakpihak lainnya, seperti tetangga dan pihak perujuk. Dukungan sosial keluarga dalam pengasuhan anak juga diidentifikasi oleh pekerja sosial, namun hanya sebatas pada keberadaan keluarga besar. Hal ini dikarenakan keluarga besar memiliki peran dalam membantu proses pengasuhan anak ketika orang tua mengalami hambatan dalam pengasuhan. Pekerja sosial juga melakukan identifikasi terhadap budaya dan norma yang ada di lingkungan sekitar keluarga. Aspek yang dilihat diantaranya adalah dialek, logat, intonasi, dan volume masyarakat sekitarnya dalam berbicara. Hal tersebut diketahui pada saat pekerja sosial melakukan kunjungan ke rumah keluarga. Selain itu, pekerja sosial juga melakukan asesmen terhadap kondisi ekonomi keluarga, yakni dengan mengidentifikasi penghasilan, pekerjaan, kondisi tempat tinggal keluarga, serta kemampuan keluarga secara finansial dalam memenuhi kebutuhan dasar anak.

Pada tahap asesmen ini, tidak semua pekerja sosial menggunakan pedoman asesmen dari lembaga dalam pelaksanaan asesmen. Padahal, pedoman asesmen telah disediakan oleh lembaga. Selain itu, beberapa pekerja sosial juga tidak melakukan proses asesmen secara menyeluruh, sesuai dengan aspek-aspek yang dikembangkan oleh Gaudin (1993), di mana beberapa di antaranya hanya fokus pada kondisi ekonomi keluarga, sehingga kondisi ekonomi keluarga menjadi alasan utama bagi pekerja sosial dalam memutuskan penempatan anak di lembaga. Keputusan mengenai rencana intervensi dan intervensi dalam hal ini dilakukan dengan melihat kondisi ekonomi serta kesanggupan keluarga untuk memberikan pengasuhan kepada anak.

\section{Perencanaan Intervensi dan I ntervensi}

Pelayanan di RPSAA Ciumbuleuit Kota Bandung hanya ditujukan untuk anak asuh saja, sehingga perencanaan dan pelaksanaan intervensi difokuskan pada anak-anak asuh yang berada di lembaga tersebut. Namun, RPSAA Ciumbuleuit juga sempat menyediakan pelayanan lainnya, khususnya bagi keluarga, yakni pelayanan berupa penguatan yang dilakukan melalui seminar Good Parenting. Kegiatan ini biasanya diadakan setahun sekali secara rutin. Namun belakangan ini, kegiatan tersebut mengalami berbagai hambatan, di antaranya tidak semua keluarga mengikuti seminar tersebut, karena adanya kendala jarak tempat tinggal sejumlah keluarga yang bertempat tinggal di luar wilayah Kota Bandung ke lokasi seminar, yakni RPSAA Ciumbuleuit Kota Bandung. Selain itu, semenjak adanya pandemi COVID-19, program tersebut sudah tidak lagi diadakan, karena disamping tidak adanya dana akibat pandemi, hal ini juga dihentikan guna mencegah terjadinya penyebaran virus COVID-19.

Seminar Good Parenting yang diadakan oleh RSPAA Ciumbuleuit bertujuan untuk memberikan pengetahuan mengenai pengasuhan anak kepada keluarga. Seminar tersebut diselenggarakan melalui kerja sama lembaga dengan Politeknik Kesejahteraan Sosial (Poltekesos). Seminar tersebut merupakan pelayanan satu-satunya yang disedeiakan RSPAA ciumbuleuit untuk keluarga.

\section{Evaluasi}

Proses evaluasi oleh RSPAA Ciumbuleuit Kota Bandung dilakukan terhadap anak asuh saja. Hal tersebut karena fokus lembaga hanya menyediakan pelayanan bagi anak.

\section{Terminasi}

Terminasi merupakan tahapan yang dilakukan oleh RPSAA Ciumbuleuit Kota Bandung untuk menghentikan layanan terhadap anak dan mengembalikan anak ke pengasuhan berbasis keluarga. Sebelum tahap ini dilakukan, pekerja sosial melakukan diskusi dengan keluarga mengenai rencana keluarga dalam pengasuhan anak serta perkembangan anak. Pada tahap ini, anak tidak langsung dikembalikan ke keluarga, namun pekerja sosial memberikan informasi terlebih dahulu kepada keluarga mengenai perkembangan anak, sehingga keluarga dapat memberikan pengasuhan sesuai 


\begin{tabular}{|l|l|l|l|l|}
\hline Share: Social Work Jurnal & VOLUME: 11 & NOMOR: 2 & HALAMAN: $81-88$ & $\begin{array}{c}\text { ISSN: 2339-0042 }(\mathrm{p}) \\
\text { ISSN: 2528-1577 }(e) \\
\text { DOI: 10.24198/share.v11i2.37040 }\end{array}$ \\
\hline
\end{tabular}

dengan kondisi anak pada saat anak kembali ke dalam pengasuhan keluarga.

\section{Tindak Lanjut}

Tahap tindak lanjut (follow-up) yang dilakukan oleh pekerja sosial yang bertugas di RPSAA Ciumbuleuit Kota Bandung dilakukan dengan melakukan komunikasi bersama keluarga untuk mengetahui informasi mengenai perkembangan mereka, dan memastikan bahwa kondisi ekonomi dan kemampuan keluarga dalam memenuhi kebutuhan dasar anak telah membaik. Jika hal tersebut belum tercapai, maka pekerja sosial akan memberikan pembahaman kepada keluarga mengenai hak anak, khususnya anak usia sekolah, dan anak akan ditempatkan kembali di lembaga. Tetapi jika anak telah menyelesaikan pendidikan Sekolah Menengah Atas (SMA), maka pekerja sosial akan menyerahkan pengasuhan dan permasalahan tersebut kepada orang tua atau keluarganya, karena pelayanan yang dilakukan oleh RPSAA Ciumbuleuit Kota Bandung hanya ditujukan bagi anak-anak usia Sekolah Dasar (SD) hingga Sekolah Menengah Atas (SMA).

Proses pelayanan bagi keluarga terdiri dari beberapa tahap, yakni pendekatan awal, asesmen, perencanaan intervensi, intervensi, evaluasi, terminasi, dan tindak lanjut (Johnson \& Yanca, 2010). Proses asesmen terhadap keluarga meliputi kegiatan identifikasi terhadap tipe penelantaran, penggalian informasi mengenai perspektif orang tua/pengasuh mengenai masalah utama yang dihadapi oleh keluarga, faktor-faktor penyebab penelantaran, penetapan prioritas penyelesaian masalah, serta pengukuran asesmen terstruktur (Gaudin, 1993). Setelah itu, intervensi dilakukan dengan menyediakan sejumlah pelayanan yang konkrit dan mendukung dari berbagai sumber, serta kombinasi dari metode individual, keluarga, dan kelompok, yang meliputi konseling individu, metode perilaku, pendidikan parenting secara individu maupun kelompok, dan terapi keluarga (Gaudin, 1993). Selain menyediakan sejumlah pelayanan, intervensi juga dapat melibatkan para profesional dari berbagai bidang keilmuan, yang dapat memberikan berbagai macam pelayanan, seperti perwakilan dari kesejahteraan anak, penegak hukum, pengadilan, sekolah, rumah sakit, departemen kesehatan, dan lembaga-lembaga kesehatan mental (Gaudin, 1993). Intervensiintervensi tersebut diberikan sesuai dengan kebutuhan dan permasalahan yang dialami oleh keluarga, serta harus difokuskan pada seluruh anggota keluarga (McClennen, 2010).

Pelayanan bagi keluarga dalam proses perlindungan anak terlantar di Rumah Perlindungan
Sosial Asuhan Anak (RPSAA) Ciumbuleuit Kota Bandung belum dilaksanakan secara maksimal, di mana tidak semua pekerja sosial melakukan proses asesmen secara menyeluruh terhadap keluarga, karena tidak semua pekerja sosial di lembaga tersebut menggunakan pedoman asesmen yang tersedia dalam mengidentifikasi permasalahan keluarga dan cenderung memandang dan menjadikan kondisi ekonomi keluarga sebagai faktor penyebab dan masalah utama yang menghambat kapasitas pengasuhan anak di dalam keluarga. Selain itu, pelayanan yang diberikan hanya difokuskan pada anak asuh saja. Sedangkan proses asesmen adalah tahap penting dalam penentuan intervensi yang tepat dan sesuai dengan permasalahan dan kebutuhan anak dan keluarga. Selain itu, pelayanan bagi keluarga dalam proses perlindungan anak terlantar merupakan pelayanan yang perlu dilaksanakan untuk memperbaiki dan meningkatkan keterampilan orang tua dalam memberikan kebutuhan dasar anak serta pengasuhan yang layak bagi anak.

Oleh karena itu, lembaga perlu mengatur kembali pelaksanaan asesmen oleh pekerja sosial agar proses asesmen dilakukan secara menyeluruh, sesuai dengan aspek-aspek yang dikembangkan oleh Gaudin (1993), DePanfilis (2006), maupun pedoman asesmen yang telah dibuat oleh lembaga. Selain itu, lembaga juga perlu memberikan pelayanan bagi keluarga dan mendukung pengasuhan berbasis keluarga, dengan mengadakan pelayanan-pelayanan bagi keluarga yang sesuai dengan permasalahan dan kebutuhan masing-masing keluarga. Dalam hal ini, pekerja sosial perlu menyediakan berbagai metode pelayanan dan bekerjasama dengan para profesional yang ahli di berbagai bidang, sesuai dengan permasalahan dan kebutuhan keluarga.

\section{SI MPULAN DAN SARAN}

Pelayanan bagi keluarga dalam proses perlindungan anak terlantar oleh Rumah Perlindungan Sosial Asuhan Anak (RPSAA) Ciumbuleuit Kota Bandung masih perlu dikembangkan, baik pada tahap asesmen, rencana intervensi, intervensi, evaluasi, terminasi, maupun tindak lanjut.

Pada tahap asesmen, pekerja sosial mengidentifikasi aspek yang berbeda-beda, dan asesmen holistik mengenai tipe penelantaran dan faktor-faktor penyebab penelantaran anak hanya dilakukan oleh beberapa pekerja sosial. Selanjutnya, pelayanan yang diberikan bagi keluarga pun masih terbatas, yaitu dalam bentuk seminar penguatan keluarga atau seminar Good Parenting, di mana pelayanan tersebut belum dapat 


\begin{tabular}{|c|c|c|c|c|}
\hline Share: Social Work Jurnal & VOLUME: 11 & NOMOR: 2 & HALAMAN: $81-88$ & $\begin{array}{c}\text { ISSN: 2339-0042(p) } \\
\text { ISSN: 2528-1577 (e) } \\
\text { DOI: } 10.24198 / \text { share.v11i2.37040 }\end{array}$ \\
\hline
\end{tabular}

memenuhi kebutuhan masing-masing keluarga yang berbeda-beda. Lembaga seharusnya menyediakan berbagai jenis dan metode layanan lainnya bagi keluarga yang sesuai dengan masalah dan kebutuhan keluarga, seperti konseling individu, metode perilaku, terapi keluarga, serta pemberian akses keluarga terhadap bantuan dari para profesional dari berbagai bidang yang dibutuhkan oleh keluarga, seperti psikolog, psikiater, dokter, dan lain sebagainya. Proses evaluasi pun tidak dilakukan terhadap keluarga, dan reunifikasi keluarga dengan anak dilakukan tanpa adanya upaya peningkatan kapasitas pengasuhan keluarga terlebih dahulu yang sesuai dengan permasalahan dan kebutuhan keluarga. Selain itu, pelaksanaan tindak lanjut terhadap keluarga cenderung fokus pada kondisi ekonomi keluarga, di mana kondisi keluarga tersebut dijadikan sebagai indikator utama dalam menentukan kondisi pengasuhan anak berbasis keluarga yang membaik.

Oleh karena itu, diperlukan penerapan proses asesmen yang holistik atau menyeluruh oleh seluruh pekerja sosial agar intervensi yang diberikan sesuai dengan permasalahan dan kebutuhan keluarga. Lembaga juga perlu melakukan pengembangan pada intervensinya terhadap keluarga yang sesuai dengan permasalahan dan kebutuhan keluarga agar keluarga memiliki kemampuan untuk memberikan pengasuhan optimal yang berkelanjutan saat anak reunifikasi dengan keluarga. Selain itu, lembaga perlu melakukan evaluasi terhadap perkembangan keluarga secara rutin dan konsisten untuk meningkatkan kualitas pelayanan dan pencapaian tujuan lembaga.

Selanjutnya, bagi penelitian selanjutnya, penelitian ini diharapkan dapat menjadi bahan rujukan bagi penelitian selanjutnya, terutama mengenai efektivitas pelayanan bagi anak dan keluarga oleh RPSAA Ciumbuleuit Kota Bandung. Dengan begitu, penelitian tersebut dapat menjadi bahan masukan bagi lembaga dalam mengembangkan pelayanannya yang mendukung pengasuhan berbasis keluarga.

\section{UCAPAN TERI MA KASI H}

Penulis mengucapkan terima kasih kepada semua pihak yang telah berkontribusi dalam penelitian dan penulisan artikel ini, khususnya kepada Program Pascasarjana Kesejahteraan Sosial Fakultas IImu Sosial dan IImu Politik Universitas Padjadjaran yang telah memberikan kesempatan kepada penulis untuk menulis artikel ini.

\section{DAFTAR PUSTAKA}

Barnett, Ola W., Miller-Perrin, Cindy L., \& Perrin, Robbin D. 2011. Family Violence Across the Lifespan: An Introduction. Thousand Oaks: SAGE Publications.

Bigner, J. J. \& Gerhardt, C. 2014. Parent-Child Relations: An Introduction to Prenting (9th $E d$.). New Jersey: Pearson Education, Inc.

Browne, K. (2009). The Risk of Harm to Young Children in Institutional Care. UK: Save the Children.

DePanfilis, Diane. 2006. Child Neglect: $A$ Guide for Prevention, Assessment, and Intervention. Washington D.C.: U.S. Department of Health and Human Services, Administration for Children and Families, Administration on Children, Youth and Families, Children's Bureau, Office on Child Abuse and Neglect.

Fernandez, E. 2013. Accomplishing Permanency: Reunification Pathways and Outcomes for Foster Children. New York: Springer.

Garfunkel, L. C., Kaczorowski, J., \& Christy, C. 2007. Pediatric Clinical Advisor: Diagnosis and Treatment. USA: Elsevier Inc.

Gaudin, J. M. 1993. Child Neglect: Guide for Intervention. U.S. Department of Health and Human Services.

Hildyard, K. L., \& Wolfe, D. A. 2002. Child Neglect: Developmental Issues and Outcomes. Child Abuse \& Neglect 26: 679-695.

Johnson, R., Browne, K. D., \& Hamilton-Giachritsis, C.F. 2006. Young Children in Institutionoal Care at Risk of Harm. Trauma, Violence, and Abuse 7(34): 34-60.

Johnson, L. C. \& Yanca, S. J. 2010. Social Work Practice: $A$ Generalist Practice with Organizations and Communities ( $\sigma^{\text {th }} E d$.). Pacific Grove, CA: Brooks/Cole.

McClennen, J.C. 2010. Social Work and Family Violence: Theories, Assessment, and Intervention. New York: Springer Publishing Company.

McCoy, Monica L. \& Keen, Stefanie M. 2014. Child Abuse and Neglect (2nd Ed.). New York \& England: Psychology Press.

Mulder, T. M., Kuiper, K. C., Van der Put, C. E., Stams, G. J. M., \& Assink, M. 2018. Risk Factors for Child Neglect: A Meta-Analytic Review. Child Abuse \& Neglect 77: 198-210.

Preston-Shoot, M. 2007. Social Workers and Child Protection. Dalam Meadow, S. R., Mok, J., \& Rosenberg, D. (ed.). "ABC of Child Protection $\left(4^{\text {th }}\right.$ Ed.)". Selected Reading, hlm. 78-82. UK: Blackwell Publishing Ltd.

Santoso, H. 2005. Disini Matahariku Terbit. J akarta: PT. Gramedia. 
Stith, S. M., Liu, T., Davies, L. C., Boykin, E. L., Alder, M. C., Harris, J. M., Som, A., McPherson, M., \& Dees, J. E. M. E. G. 2009. Risk Factors in Child Maltreatment: A MetaAnalytic Review of the Literature. Aggression and Violent Behavior 14(1): 13-29. 